\title{
Investigations on the Occurrence of Hereditary Diseases in the Danish Cattle Population 1989-1991
}

\author{
By J. S. Agerholm, A. Basse and K. Christensen
}

Department of Pathology and Epidemiology, National Veterinary Laboratory, Copenhagen, Department of Pharmacology and Pathobiology, Laboratory of Veterinary Pathology, and Department of Animal Science and Animal Health, Division of Animal Genetics, Royal Veterinary and Agricultural University, Frederiksberg, Denmark.

\begin{abstract}
Agerholm, J.S., A. Basse and K. Christensen: Investigations on the occurrence of hereditary diseases in the Danish cattle population 1989-1991. Acta vet. scand. 1993, 34, 245-253. - The methods of the Danish Bovine Genetic Disease Programme are outlined, and the results obtained during the first 3 years in function are described. The most common disease reported was spinal muscular atrophy in calves of the Red Danish Dairy breed with 312 reports. Necropsy was performed on 162 cases, and spinal muscular atrophy was diagnosed in 82 of these. Bovine progressive degenerative myeloencephalopathy, rectovaginal constriction, syndrome of arthrogryposis and palatoschisis, hereditary chondrodysplasia (2 different types), syndactylism, epitheliogenesis imperfecta, and osteogenesis imperfecta was diagnosed with 1 case each. Lethal trait A46 was diagnosed in 4 calves. Some of these diseases have not previously been described in Denmark, and epitheliogenesis imperfecta was for the first time diagnosed in the Hereford breed. Chromosome translocation 1/29 was detected in the Blonde d'Aquitaine (BAQ), Limousine, and Red Danish Dairy breed. The aberration occurred frequently in BAQ. Furthermore, a complex chromosome translocation $\mathrm{t}(1 ; 8 ; 9)(\mathrm{q} 45 ; \mathrm{q} 13 ; \mathrm{q} 26)$ was detected in the Red Danish Dairy breed.
\end{abstract}

spinal muscular atrophy; weaver syndrome; lethal trait A46; epitheliogenesis imperfecta; rectovaginal constriction; syndactylism; osteogenesis imperfecta; chromosome translocation.

\section{Introduction}

Widespread use of artificial insemination (AI) and intensive international trade with breeding animals and semen are important components of modern cattle breeding. These methods have made it possible to exploit economic important genetic traits in individual bulls to a large extent. However, such practice can be disadvantageous, if a bull is carrier of an injurious trait, e.g. a hereditary disease. These conducts are further aggravated by a common breeding practice, in which the sons of important breeding bulls are very often used for AI too, resulting in the occurrence of calves with hereditary diseases or congenital malformations. As most hereditary diseases are inherited autosomal recessively, they are often difficult to detect, and they are often first recognized when the gene frequency in the population is relatively high resulting in a large number of defective calves. Therefore, identification of disadvantageous traits at an early stage is of great economic importance for cattle breeders and breeding associations. The recognition of the presence of hereditary diseases or malformations can be advanced by the use of surveillance programmes. Due to 
the occurrence of several hereditary diseases in the Danish cattle population during the last decades, a surveillance programme, the Danish Bovine Genetic Disease Programme, was instituted in Denmark in 1988 and became functional from January 1989. This article describes the findings concerning hereditary diseases made under this programme during the first 3 years in function.

\section{Materials and Methods}

\section{The Danish Bovine Genetic Disease Pro- gramme}

The investigations were performed under the Danish Bovine Genetic Disease Programme. The system is based on reports from farmers, advisers, inseminators, meat inspectors, and veterinary practitioners. These persons report suspected cases to either the National Veterinary Laboratory (NVL) or the National Committee on Danish Cattle Husbandry (NCDCH). All reports submitted to $\mathrm{NCDCH}$ are passed on to NVL. Pedigree information of reported cases going back 3 generations are obtained from the owner or NCDCH. All reports are recorded chronologically and according to: the body system primarily affected, breed, father, and grandfathers, and the reports are evaluated for systematical familiar patterns. Based on these informations further studies on future cases are initiated.

A reported case is initially placed in 1 of 4 categories: A) cases of known hereditary diseases or malformations, B) cases of suspected hereditary aetiology, C) cases which are not suspected to be of hereditary origin, and D) inconclusive cases. Cases from group A and B are always examined further, often by necropsy. However, cases of bovine progressive degenerative myeloencephalopathy (weaver syndrome) and rectovaginal constriction (RVC) are examined clinically too, and cases of lethal trait A46 are submitted to clinical testing. Suspected cases of lethal trait A46 are given zinc fodder additive and following eventual recovery, the treatment is suspended to check the reoccurrence of symptoms. An exception from the general rule concerning category $\mathrm{A}$ are cases of hereditary diseases which occur in large numbers. When a bull is detected to be a carrier based on identification of the disease in 2 or 3 of its progeny, further cases with that particular bull as father are merely recorded. Selected cases belonging to group $\mathrm{C}$ or $\mathrm{D}$ are necropsied.

In addition to the above mentioned investigations, population studies can be performed concerning specific defects, e.g. chromosome aberrations.

The results of the examinations performed at NVL are sent to NCDCH which contacts the breeding associations and steps are taken to reduce the spread of the genetic trait. A committee concerning hereditary diseases in cattle has been established by the Danish Veterinary Service (DVS). From October 1992 hereditary diseases in cattle have become notifiable, and DVS can ban or limit the use for AI of bulls which are carriers of hereditary diseases.

\section{Laboratory procedures}

Calves being malformed or suspected of having a hereditary disease are submitted for necropsy. Before euthanasia, blood samples are taken for parentage control, and in cases of malformations also for chromosome analysis which is performed on cultured lymphocytes (Christensen et al. 1992). In cases of stillborn malformed calves the chromosome analysis is performed on cultured fibroblasts according to Freshney (1983). The calves are subjected to standard necropsy, and tissue samples for histopathology are taken from all major organs and eventually other tissues according to the macroscopic findings. These 
samples are normally fixed in $10 \%$ neutral buffered formalin and following normal laboratory preparation, the samples are paraffin embedded, sliced and routinely stained with haematoxylin-eosin. Additional staining methods are used on indication. Selected cases are submitted for electron microscopic studies. Samples from lung and spleen are examined for the presence of bovine virus diarrea (BVD) virus and blood samples or pleural liquid for presence of BVD antibodies. Bacteriology, parasitology, haematology, biochemistry, radiology, and other methods are added on indication.

\section{Results}

A total of 617 reports were received from 1989 to 1991 . This article only describes the reports belonging to group A to which 332 reports were categorized initially. The most common reported hereditary disease was spinal muscular atrophy (SMA) in the Red Danish Dairy breed (RDM) with a total of 312 reports ( $94 \%$ of all group A reports). Necropsy was performed on 162 calves, and SMA was diagnosed in 82 of these. A positive diagnosis was based on finding of motor neuron degeneration in the spinal cord intumescences and neurogenic muscular atrophy (Agerholm 1992). The remaining 150 reported calves with an anamnesis of SMA were mostly calves which were progeny of known carrier bulls, but few calves which did not belong to known carrier families, were also included. However, these calves were not available for necropsy. All calves with diagnosed SMA belonged to the same families of American Brown Swiss (ABS) origin. The investigations on SMA are described separately (Agerholm \& Basse submitted).

Bovine progressive degenerative myeloencephalopathy (BPDME) was diagnosed in a 21-month old RDM X ABS heifer. The owner stated that the heifer had shown clinical symptoms already as a 7-month old calf, and that the disease had been progressive. At clinical inspection, pronounced hind leg ataxia and weakness, reduced proprioceptive reflexes, and spontaneous falls were noted. The symptoms were exaggerated when the heifer was blindfolded. Auditory, visual, and sensory functions were normal. The heifer was slaughtered, and brain and spinal cord were removed. No macroscopic lesions were present in the organs. The histopathological examination revealed lesions in spinal cord white matter, brain stem, and cerebellum. In the spinal cord white matter, multiple vacuoles of various size were present. They were either empty or contained macrophages or axonal spheroids. In the cerebellum, lesions were mainly restricted to the Purkinje cell layer, in which degenerated Purkinje cells were found. In the cortical granular layer few swollen Purkinje cell axons could be seen. The skeletal musculature was without pathological changes.

Pedigree analysis showed that the heifer was closely connected with carriers of BPDME (The Red Danish Dairy Breed Association pers. communication).

Three other possible BPDME cases were reported and examined clinically and histopathologically. However, the suspected diagnosis was rejected in all 3 cases.

Syndrome of arthrogryposis and palatoschisis (SAP) was diagnosed in a newborn Charolais calf. The calf had typical malformations. The anterior limbs had symmetrical flexion of the carpal joints and the metacarpo-phalangeal joints with reduced joint mobility and medial rotation of the carpal joints. The posterior limbs had symmetrical hyperextension of the metatarso-phalangeal joints. Furthermore, a palatoschisis and an aspiration bronchopneumonia were present. Histopathological changes were not found in the brain, spinal 


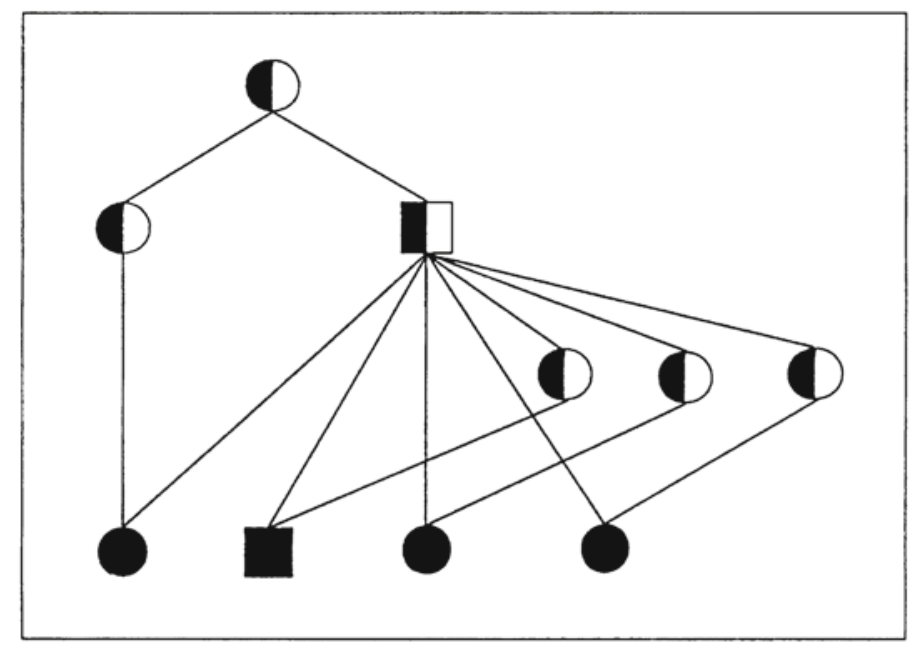

Figure 1. Genealogical diagram for 4 Holstein-Friesian calves affected with lethal trait A46.

cord, or skeletal musculature. Both parents were of the Charolais breed. Pedigree information was not available.

Lethal trait A46 was detected in 4 Danish Holstein-Friesian (SDM) calves on 1 farm. Two of these were submitted for clinical testing. At arrival they had parakeratotic lesions with a typical distribution as described by Stöber (1971). The calves were treated with a zinc fodder additive, and within a few weeks, the calves recovered, and the parakeratotic changes disappeared. After discontinuation of the treatment a recidiv was observed in both calves. The calves were then returned to the owner. The third calf was treated in the same manner on the farm, and similar observations were made. The fourth calf developed parakeratosis when it was a few weeks old. The calf died before the diagnosis was confirmed by clinical tests.

Pedigree analysis of the 4 calves revealed that they were all progeny of the same bull which was used for natural breeding on the farm, and that they occurred as the result of close inbreeding (Fig. 1). It was not possible to detect known carriers in the pedigree.

Four Jersey heifers suspected of being affected with rectovaginal constriction (RVC) were reported. Three of them were examined clinically, and the diagnosis was rejected. The fourth heifer was reported after slaughter. Caesarian section had been performed on this heifer at calving due to severe vaginal constriction and dystocia, and as the heifer was related to known carriers of RVC, this was probably a case of RVC.

Syndactylism was detected in a SDM calf which had syndactyly on both anterior limbs. The aetiology of this case remains unknown. The father which was a heavily used AI bull, was declared as being a non-carrier of syndactylism based on test breeding (father-daughter testing). Furthermore, this bull had been used for approx. 300.000 inseminations without report of other cases. The description of this case has been published separately (Nielsen \& Jensen 1990)

Hereditary types of chondrodysplasia were observed twice. Hereditary chondrodysplasia occurred in a RDM calf. The clinical and 


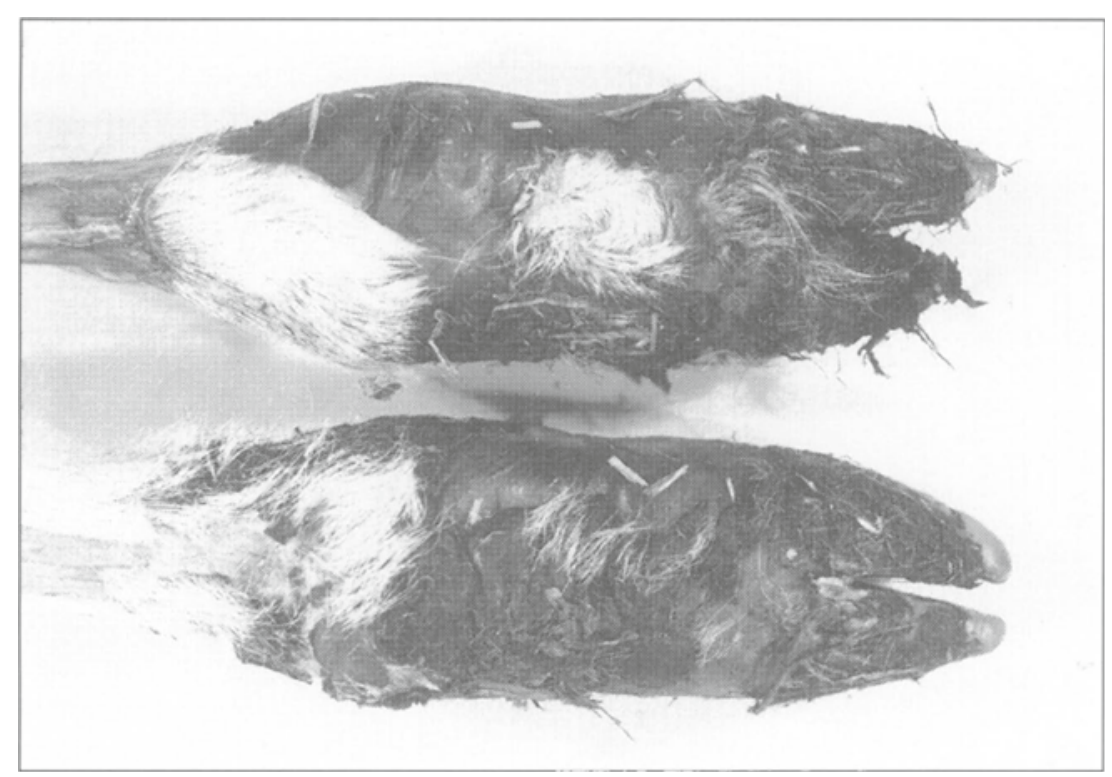

Figure 2. Epitheliogenesis imperfecta in a Horned Hereford calf. Dorsal view on the distal parts of the hind limbs showing epidermal defects and loss of a claw capsule.

pathological findings were typical, and similar to previously described cases (Andresen et al. 1974). Pedigree analysis revealed familiar relationship to known carriers. Furthermore, a typical Dexter "bulldog" calf was submitted for necropsy. The findings were similar to other described cases (Crew 1924).

Epitheliogenesis imperfecta (EI) occurred in a newborn Horned Hereford calf. The calf had typical lesions consisting of symmetrical absence of epidermis on the distal parts of all 4 limbs, loss of several claw capsules (Fig. 2), epidermal defects on the nostrils and superior lips, and epithelial defects on the tongue.

Pedigree analysis showed that the calf occurred as a result of inbreeding (Fig. 3), and that there were 3 common ancestors which could be carriers of the defect. The figure shows, that the defective calf could be caused by an autosomal recessive gene. However, this could not be proved.
Osteogenesis imperfecta (OI) was diagnosed in a newborn SDM calf. All joints on the appendicular skeleton were hypermobile, and many had subluxation/luxation and acute periarticular haemorrhage. The ligaments were poorly developed and had decreased strength. The front legs were arthrogrypotic with pronounced curvature of radius and ulna with epiphysiolysis of the distal epiphyseal line. The right femo-tibial joint and both carpophalangeal joints were severely luxated with rupture of all ligaments, periarticular musculature, and cutis resulting in exposure of the articular surfaces. Complete fractures were present on the right metatarsus and left femur. The diaphysis of left tibia and fibula were bowed. The ribs and mandibular bones had multiple fractures. The atlanto-occipital and atlanto-axis joints had subluxation and periarticular bleeding. The cutis had decreased strength and could easily be torn apart. Scle- 


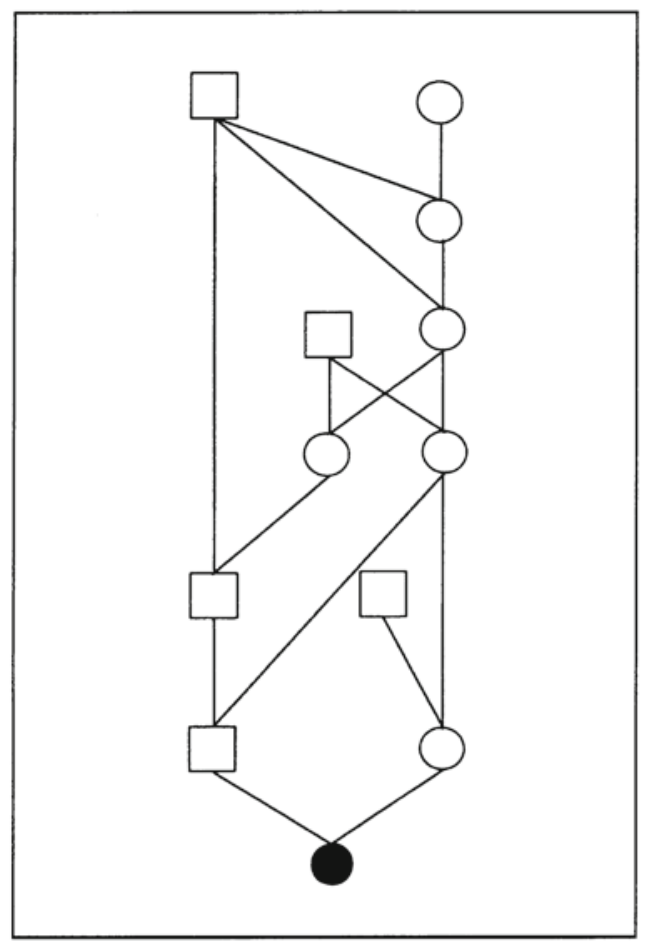

Figure 3. Genealogical diagram for a Horned Hereford calf with epitheliogenesis imperfecta.

rae were light blue, and the teeth had decreased strength. In addition to previously mentioned lesions, radiological examination showed older (intrauterine) fractures of the ribs with callus formation.

Pedigree analysis showed a common ancestor to both parents 3 generations back. Several bulls in the pedigree, including the common ancestor, were important Holstein-Friesian AI bulls.

A minor investigation on the occurrence of carriers of hereditary citrullinaemia in SDM bulls was performed without detecting any carriers (Thomsen \& Nielsen 1991).

Investigation on the occurrence of chromosome translocation $1 / 29$ in beef cattle breeds was instituted in 1989 on the background that some affected animals were detected in connection with export of Blonde d'Aquitaine cattle (BAQ) from Denmark to Sweden. Cytogenetic analysis of these exported animals was performed by professor I. Gustavsson, Sweden, who detected several cases (I. Gustavsson - pers. communication). Based on these findings, a screening programme of the Danish BAQ population and beef cattle bulls used for AI was instituted. Several cases were found in the BAQ population (Nielsen \& Christensen 1989) and among AI bulls of the Limousine breed (Nielsen \& Christensen 1990). Table 1 shows the results of this screening programme. In 1989 it was reported from USA, that semen from an ABS bull which was carrier of a complex chromosome translocation $\mathrm{t}(1 ; 8 ; 9)(\mathrm{q} 45 ; \mathrm{q} 13 ; \mathrm{q} 26)$ had been exported to Denmark for use in the RDM breed (Kovács et al. 1992). Cytogenetic analysis of all progeny ( 10 calves) of this bull in Denmark was performed, and the translocation was detected in 5 out of the 10 calves. Furthermore,

Table 1. Occurrence of centric fusion translocation 1/29 in beef cattle breeds in Denmark.

\begin{tabular}{lcccc}
\hline & \multicolumn{4}{c}{ Translocation 1/29 status } \\
\cline { 2 - 5 } Breed & Normal & Heterozygous & Homozygous & Total \\
\hline Blonde d'Aquitaine & 165 & 55 & 0 & 220 \\
Limousine & 129 & 18 & 0 & 147 \\
Other breeds & 33 & 0 & 0 & 33 \\
\hline
\end{tabular}

Preliminary results published previously (Nielsen \& Christensen 1989 \& 1990; Nielsen 1991) are included in this table. 
1 of these calves carried a 1/29 translocation (Christensen et al. 1992).

\section{Discussion}

The investigations showed that several hereditary diseases occur in the Danish cattle population. Some of these are frequent while others occur sporadic. Spinal muscular atrophy was the most frequent disease reported with approx. 230 cases in which the disease was either diagnosed or strongly suspected due to progressive recumbency and familiar relationship to known carriers. However, many cases were not reported, since statistical investigations based on insemination data of carrier bulls have revealed, that in the period 1989-1991 approx. 700 calves with SMA were born (Nygaard 1992).

The gene for bovine progressive degenerative myeloencephalopathy was introduced to the RDM population by import of semen from ABS bulls which were carriers of the disease (Hansen 1984). Descriptions of clinical cases in Denmark have not been published previously, but in the period from 1984 to 1988 several cases were detected (K.M. Hansen - pers. communication). The clinical symptoms and histopathological changes of the case described here, were similar to previously described cases in ABS (Stuart \& Leipold 1983, $1985)$. In the 1980 s, a programme to decrease the spread of BPDME was instituted. This programme seems to have been effective as only 1 case was found from 1989 to 1991 .

Syndrome of arthrogryposis and palatoschisis in Charolais calves is a hereditary malformation which occurs in many countries. The described case, which is the first diagnosed in Denmark, had characteristic malformations and was similar to other described cases (Leipold et al. 1969, 1970). However, hydromyelia and syringomyelia which is present in some cases, was not found.
Lethal trait A46, rectovaginal constriction, and syndactylism have been described in Danish cattle breeds previously and have been relatively common due to the use of carrier bulls for AI (Andresen et al. 1970, Hansen \& Elleby 1985, Nielsen \& Jensen 1990), However, breeding measures have now combatted these diseases effectively.

Hereditary chondrodysplasia in RDM calves also seems to occur seldom. The detected case occurred as a result of inbreeding, and the bulls identified as being carriers were only used for AI to a small extent. Chondrodysplasia in aborted Dexter calves have not previously been described in Denmark, but without doubt cases have occurred as this malformation is closely associated with the Dexter breed (Crew 1924).

Previously, epitheliogenesis imperfecta has not been described in the Hereford breed. However, EI has occurred in other breeds, and the defect in Hereford seems similar to EI in Holstein-Friesian, Aberdeen Angus, and Swedish Red and White cattle (Dyrendahl 1956, Jayasekara \& Leipold 1979, Leipold et al. 1973). In Denmark, EI has previously been noticed in the RDM and SDM breeds (Rasbech 1960).

Osteogenesis imperfecta is an inherited connective tissue disorder. This defect has been reported in Charolais in Denmark and Holstein-Friesians in the United States and Australia (Denholm \& Cole 1983, Jensen et al. 1976, Termine et al. 1984). The described case had many similarities in common with previous reported cases. OI in cattle is inherited as an autosomal dominant character probably occurring due to new mutations in the germ cells (Jubb et al. 1993).

The identification of chromosome translocation 1/29 in BAQ cattle in Denmark is not surprising as this defect occurs with a high frequency in that particular breed in France from where the animals were imported (Cribiu \& 
Popescu 1980). The recognition of chromosome defects in AI bulls is of great importance. The primary effect of such defects is reduced fertility due to increased embryonic death caused by formation of unbalanced gametes (Gustavsson 1969).

In conclusion, surveillance programmes can facilitate the recognition of hereditary diseases. However, some diseases are difficult to discover. Thus, a recently discovered hereditary disease, bovine leukocyte adhesion deficiency (BLAD), was not detected in the Danish Bovine Genetic Disease Programme until a specific search was instituted. Analysis of breeding results has suggested that approx. 450 calves affected with BLAD were born in 1991 (Jørgensen et al. 1993), but BLAD affected calves were not reported prior to January 1992 (Agerholm et al. 1993).

\section{Acknowledgements}

We are grateful to the Danish breeding associations, the National Committee on Danish Cattle Husbandry, the Danish Veterinary Service, and to the Department of Radiology and the Division of Large Animal Medicine, the Royal Veterinary and Agricultural University for cooperation. The investigations were supported by a grant from the Danish Research Academy, the National Committee on Danish Cattle Husbandry, and the National Veterinary Laboratory.

\section{References}

Agerholm JS: Undersøgelser over forekomsten af arvelige sygdomme og udviklingsanomalier i den danske kvægpopulation. (Investigations on the occurrence of hereditary diseases and congenital malformations in the Danish cattle population). $\mathrm{PhD}$ Thesis, The Royal Veterinary and Agricultural University and The National Veterinary Laboratory, Copenhagen, 1992.

Agerholm JS, Basse A: Spinal muscular atrophy in calves of the Red Danish Dairy breed. Vet. Rec. (submitted).

Agerholm JS, Houe H, Jørgensen CB, Basse A: Bovine leukocyte adhesion deficiency in Danish Holstein-Friesian cattle. II. Patho-anatomical description of affected calves. Acta vet. scand. 1993, 34, 237-243.

Andresen E, Christensen $K$, Jensen $P T$, Venge $O$, Rasmussen PG, Basse A, Neimann-Sørensen A, Jensen B, Nielsen J: Dværgvækst hos kvæg af Rød Dansk Malkerace (Achondroplasia bovis typus RDM). (Dwarfism in Red Danish cattle (Bovine achondroplasia: type RDM). Nord. Vet.-Med. 1974, 26, 681-691.

Christensen K, Agerholm JS, Larsen B: Dairy breed bull with complex chromosome translocation: Fertility and linkage studies. Hereditas 1992, 117, 199-202.

Crew, FAE: The significance of an achondroplasialike condition met with in cattle. Proc. Royal Society of London, Series B 1924, 95, 228-255.

Cribiu EP, Popescu CP: Distribution of the 1/29 Robertsonian translocation in France. Proc. IV Eur. Coloq. Cytogenet. Domest. Anim. 1980, 130-135.

Denholm LJ, Cole WG: Heritable bone fragility, joint laxity and dysplastic dentin in Friesian calves: a bovine syndrome of osteogenesis imperfecta. Austr. vet. J. 1983, 60, 9-17.

Dyrendahl S: Epitheliogenesis imperfecta inom SRB-rasen (Epitheliogenesis imperfecta in Swedish Red and White cattle). Nord. Vet.-Med. 1956, 8, 953-958.

Freshney, RI: Culture of Animal Cells. A manual of basic technique. Alan R. Liss, INC. New York. 1983, 1st. ed., pp. 295.

Gustavsson I: Cytogenetics, distribution and phenotypic effects of a translocation in Swedish cattle. Hereditas 1969, 63, 68-169.

Hansen KM: Weaver-syndromet hos amerikansk Brunkvæg (weaver syndrome in Brown Swiss cattle). Dansk VetTidskr. 1984, 67, 425-429.

Hansen KM, Elleby F: Anlægsbærende tyre for RVC-syndromet hos dansk Jersey-kvæg Bekæmpelsesarbejdets hidtidige forløb i Danmark. (RVC carrier bulls in Danish Jersey cattle - The fight against the RVC syndrome in Denmark). Dansk VetTidskr. 1985, 68, 941-947.

Jayasekara MU, Leipold HW: Epitheliogenesis imperfecta in Shorthorn and Angus cattle. Zbl. Vet. Med. A 1979, 26, 497-501.

Jensen PT, Rasmussen PG, Basse A: Congenital osteogenesis imperfecta in Charolais cattle. Nord. Vet.-Med. 1976, 28, 304-308.

Jubb KVF, Kennedy PC, Palmer N: Pathology of Domestic Animals vol. 1. Academic Press, Inc. San Diego. 1993, 4th. ed., p. 42-43.

Jørgensen CB, Agerholm JS, Pedersen J, Thomsen 
PD: Bovine leukocyte adhesion deficiency in Danish Holstein-Friesian cattle. I. PCR screening and allele frequency estimation. Acta vet. scand. 1993, 34, 231-236.

Kovács A, Villagomez DAF, Gustavsson I, Lindblad $K$, Foote RH, Howard TH: Synaptoneal complex analysis of a three breakpoint translocation in a bull. Cytogenet. Cell Genet. 1992, 61, 195-201.

Leipold HW, Mills JHL, Huston K: Epitheliogenesis imperfecta in Holstein-Friesian calves. Can. vet. J. 1973, 14, 114-118.

Leipold HW, Cates WF, Radostits OM, Howell WE: Arthrogryposis and associated defects in newborn calves. Amer. J. vet. Res. 1970, 31, 13671374.

Leipold HW, Cates WF, Radostits OM, Howell WE: Spinal dysraphism, arthrogryposis and cleft palate in newborn Charolais calves. Can. vet. J. 1969, 10, 268-273.

Nielsen*JS: Hereditary diseases in cattle - especially of current concern in European AI-work. Proc. 3th. Meeting of A.I.-Vets in the EEC 1991, 20-30.

Nielsen*JS, Christensen K: Kromosomtranslokation 1/29 hos kvæg. (Chromosome translocation 1/29 in cattle). Dansk VetTidskr. 1989, 72, 586-590.

Nielsen*JS, Christensen K: Kromosomtranslokation 1/29 hos dansk Limousine kvæg. (Chromosome translocation 1/29 in Danish Limousine cattle). Dansk VetTidskr. 1990, 73, 1036-1039.

Nielsen* JS, Jensen KM: Bovin syndactyli hos SDM (Bovine syndactylism in a Danish Holstein-Friesian calf). Dansk VetTidskr. 1990, 73, 699-701.

Nygaard H (ed): Årsberetning 1992, Landsudvalget for Kvæg (Year book 1992, National Committee on Danish Cattle Husbandry). p. 34-35.

Rasbech NO: Arvelige misdannelser; Med henblik på registrering af letale og semiletale anlæg hos kvæg (Hereditary malformations with special regard to registration of lethal and semilethal conditions in cattle). Nord. Vet.-Med. 1960 (suppl. I), 12, 1-57.

Stuart LD, Leipold, HW: Bovine progressive degenerative myeloencephalopathy ("weaver") of Brown Swiss cattle II: clinical and laboratory findings. Bovine Pract. 1983, 18, 133-146.

Stuart LD, Leipold, HW: Lesions in bovine progres- sive degenerative myeloencephalopathy ("weaver") of Brown Swiss cattle. Vet. Pathol. 1985, 22, 13-23.

Stöber, M: Parakeratose beim schwarzbunten Niederungskalb. 1. Klinisches Bild und Ätiologi (Parakeratosis in black pied calves. 1. Clinical findings and etiology). Dtsch. tierärztl. Wschr. 1971, 78, 257-265.

Termine JD, Robey PG, Fisher LW, Shimokawa H, Drum MA, Conn KM, Hawkins GR, Cruz JB, Thompson KG: Osteonectin, bone proteoglycan, and phosphophoryn defects in a form of bovine osteogenesis imperfecta. Proc. Natl. Acad. Sci. USA 1984, 81, 2213-2217.

Thomsen PD, Nielsen*JS: PCR-screening for carriers of hereditary citrullinaemia in Danish HolsteinFriesian bulls. Acta vet. scand. 1991, 32, 279-282.

\section{Sammendrag}

Undersøgelser over forekomsten af arvelige sygdomme i den danske kvagpopulation 1989-1991. Metoderne i Det Danske Undersøgelsesprogram vedrørende Arvelige Sygdomme hos Kvæg beskrives, og der redegøres for de resultater, der er opnået i de tre første år. Den hyppigst anmeldte sygdom var spinal muskelatrofi (SMA) hos kalve af Rød Dansk Malkerace med 312 anmeldelser. Der blev obduceret 162 tilfælde blev obduceret, og SMA blev diagnosticeret i 82 af disse. Endvidere blev følgende sygdomme diagnosticeret med et tilfælde af hver: Bovin progressiv degenerativ myeloencephalopathy, rectovaginal constriction, syndrome of arthrogryposis and palatoschisis, arvelig chondrodysplasia (2 forskellige typer), syndactyli, epitheliogenesis imperfecta og osteogenesis imperfecta. Letal faktor A46 blev diagnosticeret hos fire kalve. En del af disse sygdomme er ikke tidligere beskrevet i Danmark, og epitheliogenesis imperfecta blev for første gang diagnosticeret hos Hereford. Kromosomtranslokation 1/29 blev fundet hos racerne Blonde d'Aquitaine (BAQ), Limousine og Rød Dansk Malkerace. Defekten forekom hyppigt hos BAQ. Endvidere blev en kompleks kromosomtranslokation $\mathrm{t}(1 ; 8 ; 9)(\mathrm{q} 45 ; \mathrm{q} 13 ; \mathrm{q} 26)$ påvist $\mathrm{i}$ Rød Dansk Malkerace.

* Surname changed from Nielsen to Agerholm, May 1992.

(Received March 24, 1993; accepted May 6, 1993).

Reprints may be requested from: J. S. Agerholm, Department of Pathology and Epidemiology, National Veterinary Laboratory, Bülowsvej 27, DK-1790 Copenhagen, Denmark. 